\title{
PROFESIONALISME, MOTIVASI BERPRESTASI, KOMITMEN ORGANISASI DAN PENGARUHNYA TERHADAP INTENSI BERWIRAUSAHA
}

\author{
Didit Darmawan \\ dr.diditdarmawan@gmail.com \\ Universitas Mayjen Sungkono Mojokerto
}

\begin{abstract}
Currently in Indonesia there has been an increase in unemployment and lack of employment which has caused social problems that must be resolved. The decision to become an entrepreneur is one of the solutions a person can take to play a role in reducing unemployment. The intention of entrepreneurship not only arises from someone who does not have a permanent job but can occur in groups of workers who have carried out certain professions so that if this happens it will be a problem faced by the company. Problems that occur such as the intention to turnover or reduce job loyalty. The main purpose of this study is to analyze and know the impact of professionalism, achievement motivation, organization commitment on employee entreprenuerial intention. The population in this study are employees who work in the finance department. The population in this study were 100 respondents in several companies in the cities of Surabaya, Sidoarjo, Gresik, Mojokerto and Malang who were taken based on purposive sampling technique. Analyzer in this research use multiple linear regression analysis 25 version. Finally, the results showed that professionalism have significant positive impact on employee entrepreneurial intention, achievement motivation have significant positive impact on employee entrepreneurial intention, organization commitment have significant positive impact on employee entrepreneurial intention.
\end{abstract}

Key words: professionalism; achievement motivation; organization commitment; entrepreneurial intention

\begin{abstract}
ABSTRAK
Saat ini di Indonesia terjadi peningkatan jumlah pengangguran dan kurangnya lapangan pekerjaan yang menimbulkan masalah sosial yang harus dapat diselesaikan. Keputusan untuk berwirausaha menjadi salah satu solusi yang dapat dilakukan seseorang untuk berperan mengurangi angka pengangguran. Intensi berwirausaha tidak hanya muncul dari diri seseorang yang tidak memiliki pekerjaan secara tetap namun dapat terjadi pada kelompok pekerja yang telah menjalankan profesi tertentu sehingga bila hal tersebut terjadi akan menjadi permasalahan yang dihadapi perusahaan. Permasalahan yang terjadi seperti niat untuk keluar dari pekerjaan atau berkurangnya loyalitas kerja. Tujuan dari penelitian ini, yaitu untuk menganalisis dan mengetahui pengaruh profesionalisme, motivasi berprestasi, komitmen organisasi terhadap intensi berwirausaha karyawan. Populasi pada penelitian ini, yaitu karyawan yang bekerja di departemen keuangan. Responden pada penelitian ini ada 100 responden yang ada di beberapa perusahaan di kota Surabaya, Sidoarjo, Gresik, Mojokerto dan Malang yang diambil berdasarkan teknik purposive sampling. Alat analisis yang digunakan, yaitu regresi linear berganda dengan program SPSS versi 25 . Hasil penelitian menunjukkan bahwa profesionalisme berpengaruh positif signifikan terhadap intensi berwirausaha karyawan, motivasi berprestasi berpengaruh positif signifikan terhadap intensi berwirausaha karyawan, komitmen organisasi berpengaruh positif signifikan terhadap intensi berwirausaha karyawan.
\end{abstract}

Kata kunci: profesionalisme; motivasi berprestasi; komitmen organisasi; intensi berwirausaha.

\section{PENDAHULUAN}

Di era globalisasi saat ini yang penuh dengan tantangan dan persaingan serta adanya masalah ketenagakerjaan, kualitas sumber daya manusia dan produktivitas tenaga kerja yang relatif rendah mengakibatkan banyaknya pengangguran. Pengangguran menjadi salah satu permasalahan sosial 
yang harus dapat diselesaikan. Jumlah lapangan kerja dan pencari kerja yang tidak sesuai mengakibatkan meningkatnya angka pengangguran. Langkah yang dapat dilakukan untuk menyelesaikan masalah pengangguran, yaitu dengan berwirausaha.

Berwirausaha dapat menjadi pilihan untuk bekerja, memulai karir di masa depan. Selain itu, berwirausaha juga dapat membantu tugas Pemerintah untuk mengurangi angka pengangguran dan dapat memberikan lapangan pekerjaan bagi seseorang yang membutuhkan pekerjaan. Hal ini juga sesuai dengan pernyataan dari Azhar et al. (2010) yang menyatakan bahwa berwirausaha menjadi sesuatu yang penting untuk setiap negara sejak zaman globalisasi, karena pertumbuhan kegiatan berwirausaha dapat membantu menciptakan lapangan pekerjaan bagi masyarakat, mengurangi tingkat pengangguran. Dickson et al. (2008) juga menyatakan bahwa pertumbuhan kewirausahaan penting bagi perekonomian suatu negara. Peluang yang terbatas dari pekerjaan yang dicari karena lingkungan yang kompetitif (Keat et al., 2011) dan ketidakpastian tentang pekerjaan (Fereira et al., 2012) menyebabkan negara maju dan berkembang lebih bergantung pada tingkat kewirausahaan yang lebih tinggi untuk mencapai tujuan pribadi dan pertumbuhan ekonomi.

Intensi berwirausaha tidak hanya dimulai dari seseorang yang belum memiliki pekerjaan tetap namun dapat terjadi berawal dari posisi sebagai karyawan yang beralih menjadi wirausaha. Sebagian dari mereka memutuskan berhenti dari pekerjaannya namun sebagian dari mereka memulai sebagai wirausaha dengan tetap menyandang status sebagai karyawan. Mereka akan benar-benar berhenti sebagai karyawan bila telah merasakan hasil yang menjanjikan dari usaha mandirinya. Tentu saja hal tersebut merupakan ancaman bagi penyedia kerja dengan tantangan menghadapi tingkat turnover yang tinggi karena adanya intensi berwirausaha. Perusahaan juga dituntut untuk mempunyai kemampuan meningkatkan daya saing agar dapat menjaga ke- langsungan hidup perusahaan. Perusahaan harus mampu menyesuaikan situasi dan kondisi saat ini dengan meningkatkan kualitas sumber daya manusia di perusahaan yaitu karyawan. Karyawan yang memiliki potensi untuk berkembang diharapkan dapat memberikan kontribusi berarti bagi terwujudnya tujuan perusahaan dan kelangsungan hidupnya. Mereka hanya memiliki sikap profesionalismenya, motivasi untuk berprestasi dan komitmen terhadap organisasi. Ketiga hal tersebut merupakan variabel penentu keberhasilan karyawan memberikan kontribusi bagi perusahaan namun juga menjadi variabel yang dapat menjadi indikasi munculnya intensi berwirausaha yang berarti terlepasnya hubungan karyawan dengan perusahaan.

Sikap profesionalisme dari karyawan dapat ditunjukkan dengan pengetahuan, keahlian, karakteristik. Karyawan yang tidak dapat bersikap dan bekerja secara profesional maka perusahaan menganggap karyawan tidak mampu memberikan kontribusinya secara maksimal kepada tempat mereka bekerja. Persaingan di dunia kerja yang semakin kompetitif dan adanya tuntutan dari perusahaan mengakibatkan kayawan berusaha menunjukkan sikap profesionalismenya agar dapat bertahan di perusahaan tempat mereka bekerja. Profesionalisme saat ini telah dipelajari di dalam teori manajemen dan organisasi serta dalam paradigma sosiologi atau etika bisnis (Burrage dan Torstendahl, 1990; Jemielniak, 2005). Karyawan dengan profesionalisme yang tinggi dapat dilihat dari kinerjanya dan kinerja berhubungan dengan tujuan sebagai hasil perilaku seseorang yang mempunyai profesi. Perusahaan menghargai kinerja karyawan yang menjalankan tugasnya secara profesional, bertanggung jawab, bekerja secara efektif, jujur dan memiliki integritas yang tinggi.

Hasil dari kinerja karyawan diharapkan dapat menjadikan karyawan memiliki motivasi untuk berprestasi agar mereka dapat mengembangkan karirnya. Motivasi adalah dasar yang penting untuk mencapai ke- 
terampilan perencanaan, pengorganisasian dan membuat kebijakan dan hal ini juga sebagai dasar untuk pembelajaran dan penilaian di negara Indonesia sebagai perilaku kognitif (Pintrich dan Schunk, 1996). Menurut Sénchez dan Sahuquillo (2012), motivasi didasarkan pada emosi dan tujuan yang berhubungan dengan prestasi, kebutuhan untuk pencapaian diri telah dihubungkan dengan perilaku kewirausahaan. McClelland (1961) berpendapat bahwa seseorang yang mempunyai prestasi tinggi juga harus lebih menyukai pekerjaan yang melibatkan keterampilan dan usaha, memberikan timbal balik kinerja yang jelas dan memiliki tantangan serta resiko yang sedang dan kondisi tersebut juga lebih banyak ada pada posisi berwirausaha daripada posisi yang lain.

Motivasi berprestasi yang telah ditunjukkan oleh karyawan menunjukkan bahwa karyawan telah memberikan kontribusinya terhadap perusahaan melalui komitmen organisasi. Komitmen organisasi telah menjadi pembahasan yang sangat penting dalam psikologi industri atau organisasi. Karyawan yang memiliki komitmen kuat terhadap organisasi cenderung tetap ingin bertahan. Eslami dan Gharakhani (2012) berpendapat bahwa komitmen sebagai peraturan yang berusaha menjelaskan konsistensi yang melibatkan sikap, nilai-nilai, perilaku dan melibatkan pilihan perilaku. Beberapa penelitian menunjukkan bahwa karyawan yang berkomitmen memiliki keyakinan yang lebih kuat untuk menerima tujuan dan nilai-nilai organisasi, menyatakan keinginan yang lebih besar untuk mengerahkan upaya atas nama organisasi, dan memiliki keinginan yang lebih kuat untuk mempertahankan keanggotaan organisasi (Kanter, 1989; Sheldon, 1971; Mowday et al., 1979; Mowday et al., 1982; Legge, 1995) sehingga karyawan yang berkomitmen terhadap organisasi lebih cenderung bekerja secara stabil dan produktif.

Tantangan yang dihadapi oleh perusahaan, yaitu bagaimana dapat mempertahankan karyawan agar tetap bekerja secara profesional, memiliki motivasi untuk berprestasi dan bersedia untuk selalu ber- komitmen dengan organisasi. Perusahaan berusaha menyeimbangkan ketiga variabel tersebut agar karyawan tetap bertahan dan tidak memiliki niat untuk berwirausaha karena adanya keinginan untuk tidak terikat dengan perusahaan. Berwirausaha merupakan kegiatan untuk memulai usaha yang dilakukan seseorang karena merasa memiliki kemampuan untuk mencapai karir dan impian mereka sendiri tanpa bergantung pada manajer di tempat mereka bekerja. Selain itu, karyawan yang berwirausaha juga harus memiliki kemampuan secara manajerial yang berarti dapat melaksanakan planning (perencanaan), organizing (pengorganisasian), actuacting (pelaksanaan), controlling (pengawasan) atau yang biasa disebut dengan POAC. Tujuan POAC tersebut diharapkan dapat digunakan untuk mengembangkan usahanya dalam jangka waktu yang relatif lama. Karyawan yang memutuskan untuk berwirausaha memerlukan keterlibatan yang tinggi karena melibatkan faktor internal seperti kepribadian, persepsi, motivasi, pembelajaran (sikap), faktor eksternal seperti keluarga, teman, tetangga dan lain sebagainya (norma subyektif). Sikap, perilaku dan dukungan sosial yang dimiliki karyawan mengakibatkan adanya potensi untuk berwirausaha. Maes et al. (2014) juga menyatakan bahwa sikap pribadi, perilaku yang dirasakan, norma-norma sosial sebagai penentu untuk menetapkan niat seseorang berwirausaha. Sikap pribadi yang dimiliki karyawan terjadi karena adanya kelebihan, kepuasan dan daya tarik tentang kewirausahaan dan pernyataan ini sesuai dengan hasil penelitian dari Mumtaz et al. (2012). Karyawan merasa bahwa untuk menjadi wirausahawan jauh lebih mudah dan hal itu akan memotivasi mereka untuk berwirausaha. Hasil penelitian ini sesuai dengan Souitaris et al. (2007). Dukungan sosial yang besar dari orang tua, keluarga, teman dapat mempengaruhi keputusan mereka untuk berwirausaha (Nanda dan Sorensen, 2006; Altinay et al., 2012; Yurtkoru et al., 2014; Zapkau et al., 2015). Berdasarkan uraian dari latar belakang 
sebelumnya maka peneliti tertarik untuk mengambil topik penelitian, yaitu "Profesionalisme, Motivasi Berprestasi, Komitmen Organisasi dan pengaruhnya terhadap Intensi Berwirausaha"

\section{TINJAUAN TEORITIS Profesionalisme}

Di dunia kerja setiap karyawan dituntut untuk bekerja secara profesional. Profesionalisme pada diri karyawan diharapkan dapat membantu perusahaan untuk lebih baik. Profesionalisme berhubungan dengan profesi dan itu adalah kemampuan untuk melakukannya secara profesional. Karyawan yang mempunyai sikap profesionalisme akan menunjukkan kinerja secara maksimal yang diberikan kepada perusahaan. Ada beberapa definisi profesionalisme menurut para ahli, yaitu (1) Hoyle (1975) menjelaskan profesionalisme sebagai strategi yang digunakan oleh karyawan pada suatu pekerjaan dengn tujuan berupaya meningkatkan status, gaji, dan kondisi dan profesionalisme paling baik dapat dipahami dengan kebijakan. Analisis kritis terhadap profesionalisme tidak hanya menekankan kualitas yang ada dalam suatu pekerjaan tetapi mengeksplorasi nilai layanan yang ditawarkan oleh karyawan kepada perusahaan; (2) menurut Boyt et al. (2001) profesionalisme terdiri dari sikap dan perilaku yang dimiliki seseorang terhadap profesinya dan ini berorientasi pada sikap dan perilaku yang dimiliki individu terhadap pekerjaannya; (3) profesionalisme dapat dijelaskan sebagai suatu sikap dan perilaku tertentu dari seorang karyawan yang berhubungan dengan etos organisasi dan memiliki kesimpulan untuk memotivasi individu, bekerjasma dan berinteraksi secara profesional dengan rekan kerjanya (Epstein dan Hundert, 2002). Dari definisi profesionalisme yang sudah dijelaskan sebelumnya, dapat disimpulkan bahwa profesioanalisme adalah sikap dan perilaku yang ditunjukkan seseorang terhadap profesinya yang dapat memotivasi, bekerjasama dan beriteraksi secara profesional dengan rekan kerjanya.
Indikator profesionalisme menurut Hall (1968) ada lima, yaitu (1) pengabdian terhadap profesi, artinya profesionalisme adalah sesuatu yang ditunjukkan oleh dedikasi seseorang dengan tujuan untuk menggunakan pengetahuan, keahlian yang dimiliki; (2) kemandirian, artinya seseorang yang profesioanl harus mampu membuat keputusannya sendiri tanpa adanya tekanan dari pihak lain; (3) kewajiban sosial, artinya manfaat yang dirasakan oleh masyarakat maupun karyawan yang profesiona dari adanya suatu pekerjaan; (4) hubungan sesama profesi, artinya dengan adanya profesionalitas memberikan syarat adanya hubungan profesi dari dalam organisasi atau kelompok kolega informasi sebagai sumber ide utama pekerjaan dan dengan adanya hubungan profesi ini para profesional dapat membangun kesadaran terhadap profesinya; (5) keyakinan terhadap profesi, artinya keyakinan bahwa yang mempunyai hak untuk menilai kinerja yang profesional adalah bukan pihak yang tidak mempunyai kompetensi di bidang ilmu dan pekerjaan mereka.

\section{Motivasi Berprestasi}

Motivasi dinilai sebagai kekuatan dan kegigihan yang diperlukan untuk mencapai sesuatu dalam waktu yang ditentukan dan motivasi mengacu pada dorongan dan tujuan perilaku. Sparrow (1998) menemukan bahwa motivasi memiliki pengaruh pada pembentukan psikologis. Motivasi meliputi pekerjaan yang penting, keamanan kerja, rasa prestasi, saluran promosi, dan peluang. Seseorang yang sangat termotivasi untuk berprestasi lebih termotivasi untuk terlibat dalam kegiatan yang bersemangat dan inovatif yang membutuhkan cara berfikir untuk masa depan dan bertanggung jawab secara individu untuk hasilnya daripada seseorang yang motivasi berprestasinya rendah (McClelland et al., 1958). Motivasi berprestasi memaksimalkan rasa pencapaian pada diri sendiri yang merupakan kekuatan internal dan hal itu adalah kondisi jangka panjang yang secara langsung dapat mempengaruhi perilaku kognitif dan tingkah 
laku individu. Individu dengan motivasi berprestasi tinggi tidak dibatasi oleh kekuatan situsional dan pengaruh perubahan lingkungan. Teori tentang kebutuhan prestasi telah dikembangkan oleh McClelland pada tahun 1953. Mendol dan Marcus (2015) mengatakan bahwa untuk setiap tindakan yang dilakukan oleh manusia, motivasi yang dicapai merupakan kekuatan untuk mencapai psikologis yang penting sehingga mempengaruhi perilaku berwirausaha. Ada beberapa penelitian yang berkonsentrasi pada karakteristik psikologis yang menyatakan bahwa seseorang yang berwirausaha memiliki karakteristik yang unik. Karakteristik kewirausahaan ini dijelaskan dari literatur oleh beberapa peneliti sarjana (Schumpeter, 1934; Mitton, 1989; Robinson et al., 1991; Koh, 1996; Dinis et al., 2013) sehingga penelitian yang berhubungan dengan karakteristik kepribadian mempunyai pengaruh yang penting untuk menilai perilaku berwirausaha. Seseorang yang mempunyai motivasi berprestasi tentunya juga memiliki kemampuan untuk menyelesaikan masalah, memiliki ambisi dalam kehidupannya dan ada keinginan untuk mencapainya dengan meningkatkan kinerja mereka (Riipinen, 1994; Koh, 1996; Muller, 2008; Mendol dan Marcus, 2015) sehingga dapat dijelaskan bahwa seseorang ini mempunyai motivasi berprestasi yang lebih tinggi daripada orang lain dan mempunyai hubungan yang kuat dengan niat berwirausaha.

Menurut Holland (1985) individu akan tertarik pada karir yang menyediakan berbagai karakteristik lingkungan yang sesuai dengan kepribadian mereka dan karakteristik individu mereka serta juga berpendapat bahwa apabila karakteristik lingkungan dan kepribadian telah sesuai dengan tingkat kepuasan dan tingkat kinerja maka akan berada pada tingkat yang lebih tinggi. Hal tersebut menjadi penyebab McClelland (1961) menyatakan bahwa individu dengan motivasi berprestasi yang tinggi harus tertarik dengan kewirausahaan agar mereka dapat bekerja dengan baik dalam pekerjaan tersebut. Negara-negara yang memiliki tingkat motivasi berprestasi rata-rata yang lebih tinggi melarang lebih banyak kegiatan berwirausaha untuk pertumbuhan ekonomi dibandingkan dengan negara dengan tingkat motivasi berprestasi rata-rata yang lebih rendah (McClelland, 1961). Ada beberapa definisi motivasi menurut para ahli, yaitu (1) Motivasi berprestasi dapat dijelaskan sebagai dorongan yang ada dalam diri seseorang untuk melakukan suatu kegiatan dengan sebaik mungkin untuk mencapai tujuan pribadinya dalam bentuk prestasi (Rabideau, 2005; Ghasemi, et al., 2011; Weseley dan McEntarffer, 2010); (2) Atkinson (1964) mendefinisikan bahwa motivasi berpresatsi sebagai perbandingan kinerja dengan orang lain dan terhadap kegiatan pada standar tertentu; (3) Atkinson dan Feather (1966) menyatakan bahwa motivasi berprestasi adalah gabungan dari dua variabel kepribadian yaitu kecenderungan untuk mendekati kesuksesan dan kecenderungan untuk menghindari kegagalan; (4) Beigge dan Hunt (1980) mendefinisikan bahwa motivasi berprestasi merupakan dorongan untuk bekerja dengan ketekunan dan vitalitas serta terus mengarah untuk mencapai target; (5) Dave dan Anand (1979) menyatakan bahwa motivasi berprestasi adalah keinginan seseorang untuk berbuat baik secara relatif terhadap beberapa orang dengan standar yang lebih tinggi. Dari definisi motivasi berprestasi yang sudah dijelaskan sebelumnya, dapat disimpulkan bahwa motivasi berprestasi adalah dorongan atau keinginan seseorang untuk bekerja secara maksimal pada standar tertentu untuk mencapai kesuksesan dan menghindari kegagalan.

Indikator motivasi berprestasi menurut Helmreich dan Spence (1978) ada empat, yaitu (1) penguasaan kebutuhan, artinya seseorang yang lebih suka ketika mendapatkan pekerjaan yang menantang, secara intelektual, berorientasi pada cara berfikir, berperan sebagai pemimpin dalam kelompok serta mampu menyelesaikan tugas yang telah dimulai; (2) orientasi kerja, artinya sikap proaktif seseorang terhadap pekerjaannya dan menyukai apa yang dilakukan sehingga mendapatkan rasa puas dari 
pekerjaan dan mengejar realisasi dan pertumbuhan diri; (3) kompetisi, artinya seseorang berharap dan memiliki keinginan untuk menang; (4) pribadi yang tidak peduli, artinya seseorang tidak menganggap kesuksesan dari kinerja menjadi faktor penyebab ditolak oleh orang lain.

\section{Komitmen Organisasi}

Secara umum komitmen organisasi dapat dijelaskan bahwa sebagai hubungan psikologis antara karyawan dan organisasinya, komitmen organisasi telah ditemukan berhubungan dengan hasil pekerjaan utama, yaitu niat keluar atau masuknya karyawan dan proses yang benar-benar terjadi (Mathieu dan Zajac, 1990). Meyer dan Herscovitch (2001) menyatakan bahwa komitmen adalah kekuatan yang mengikat seseorang untuk tindakan yang relevan dengan satu target atau lebih. Komitmen organisasi dapat dinilai dengan memanfaatkan cara berfikir dan tentunya harus sesuai tujuan, apa komitmen karyawan, baik itu organisasi, tim, inisiatif perubahan, atau tujuan. Komitmen mencakup istilah perilaku yang menunjukkan tindakan apa yang dinyatakan dalam komitmen Meyer dan Herscovitch (2001). Meyer et al. (2006) menyatakan bahwa komitmen terdiri dari bagian kognitif dan afektif. Bagian kognitif merupakan istilah perilaku dan dasar dari komitmen dan afektif terdiri dari perasaan terhadap pola berfikir tertentu. Ada beberapa definisi komitmen organisasi menurut para ahli, yaitu (1) Porter et al. (1974) mendefinisikan komitmen organisasi sebagai kemampuan individu mengidentifikasi dan terlibat dalam organisasi tertentu dan komitmen tersebut dapat dilihat dengan tiga faktor, yaitu keyakinan yang kuat dan penerimaan dari tujuan serta nilai organisasi, bersedia untuk berjuang atas nama organisasi, ada keinginan yang pasti untuk mempertahankan keanggotaan organisasi; (2) komitmen organisasi merupakan kekuatan relatif dari seseorang dan terlibat dalam organisasi tertentu secara keseluruhan (Mowday et al., 1982); (3) Caught dan Shadur, (2000) me- nyatakan bahwa komitmen organisasi adalah kondisi komitmen dari karyawan untuk membantu mencapai tujuan organisai yang melibatkan tingkat identifikasi karyawan, keterlibatan dan loyalitas, hal ini menunjukkan kondisi dimana anggota organisasi terikat oleh tindakan dan keyakinan mereka yang mendukung aktivitas mereka dan keterlibatan dalam organisasi (Miller dan Lee, 2001); (4) Miller (2003) menyatakan bahwa komitmen organisasi sebagai kondisi dari seseorang karyawan mengidentifikasi dengan organisasi tertentu dan tujuannya serta ingin mempertahankan keanggotaan dalam organisasi; (5) komitmen organisasi dapat dilihat dari penilaian kesesuaian antara nilainilai dan keyakinan seseorang dan nilai-nilai organisasi (Swailes, 2002); (6) komitmen organisasi dapat ditandai dengan kesediaan karyawan untuk memberikan kontribusi sehingga dapat mencapai tujuan organisasi dan ketika karyawan merasa yakin apabila mereka akan belajar dan berkembang dengan para pengusaha saat ini maka tingkat komitmen mereka tetap bertahan pada organisasi jauh lebih tinggi (Okpara, 2004); (7) komitmen organisasi adalah hubungan keterikatan psikologis yang dikembangkan individu kepada suatu organisasi (Fiorito et al., 2007; Wright dan Kehoe, 2007). Dari definisi komitmen organisasi yang sudah dijelaskan sebelumnya, dapat disimpulkan bahwa komitmen organisasi adalah kesediaan seseorang untuk membantu, memberikan kontribusinya dan tetap bertahan untuk mencapai tujuan organisasi.

Indikator komitmen organisasi dari Meyer dan Allen (1997) ada tiga, yaitu (1) komitmen afektif berhubungan dengan keterikatan emosional, identifikasi dan keterlibatan dalam organisasi; (2) komitmen berkelanjutan adalah bentuk ikatan psikologis dengan karyawanm organisasi yang menunjukkan persepsi karyawan tentang kehilangan yang akan dirasakan jika mereka meninggalkan organisasi dan komitmen berkelanjutan melibatkan kesadaran karyawan tentang biaya yang dikeluarkan apabila meninggalkan organisasi; (3) komitmen normatif 
menunjukkan perasaan untuk tetap berkewajiban melanjutkan pekerjaan dan karyawan dengan komitmen normatif yang tinggi merasa harus tetap bekerja dengan organisasi.

\section{Intensi Berwirausaha}

Aktivitas berwirausaha dapat dilihat sebagai fungsi manajemen yang terdiri dari kegiatan di luar pekerjaan rutin yang memberikan tantangan pada cara berfikir dan perilaku manusia (B'echard dan Gr'egoire, 2005). Pada akhir abad ke 20 dan awal abad ke 21, berwirausaha menjadi salah satu pemikiran yang mencoba mendirikan sebuah kerangka kerja dan kewirausahaan serta melihat pengusaha sebagai seseorang yang dapat mempersepsikan atau meraih peluang (Bygrave dan Hofer, 1991; Venkataraman, 1997; Shane dan S.Venkataraman, 2000; Eckhardt dan Shane, 2003; Shane et al., 2003; Chabaud dan Ngijol, 2004). Beriwausaha dapat didefinisikan sebagai proses yang dibawa seseorang dari mengidenifikasi kewirausahaan yang baru sehingga menjadi peluang untuk produk atau layanan yang dapat dipasarkan (Schaper et al., 2010). Niat merupakan keadaan dari fikiran yang mengarahkan perhatian seseorang yang pada akhirnya mengarah pada pengalaman dan tindakan untuk mencapai sesuatu (Bird, 1988). Kewirausahaan terdiri dari mencari peluang, mencari informasi, perolehan sumber daya dan implementasi strategi bisnis (Madrigal et al., 2012) dan sebelum melakukan itu harus ada niat pada individu yang melakukannya.

Ada beberapa definisi niat berwirausaha menurut para ahli, yaitu (1) niat berwirausaha adalah kekuatan utama untuk memahami proses kewirausahaan, yaitu apa yang membuat seseorang termotivasi untuk menjadi wirausahawan. Secara umum model niat berwirausaha termasuk variabel tipe individu dan lingkungan. Intinya, mereka termasuk konsep self-efficacy yang artinya keyakinan individu tentang kemampuannya untuk melakukan tugas atau tindakan sehingga dapat mencapai tujuan tertentu (Krueger dan Brazeal, 1994) dan locus of internal control (Shapero dan Sokol, 1982). Self efficacy berhubungan dengan perilaku dalam situasi resiko yang tinggi dan ketidakpastian serta fleksibilitas perilaku untuk menghadapi ancaman dan situasi buruk (D’Iaz et al., 2006); (2) niat berwirausaha adalah keadaan dimana seseorang berfikir bahwa ada keinginan untuk membuat perusahaan baru atau nilai baru di dalam organisasi dan ini adalah kekuatan yang mendorong aktivitas kewirausahaan (Wu et al., 2008); (3) niat berwirausaha dapat ditunjukkan sebagai pengorbanan tenaga, fikiran serta waktu untuk memulai bisnis baru untuk mencapai tujuannya (Krueger, 1993; Mobaraki dan Zare, 2012) dan keputusan untuk berkarir mayoritas didahului dengan perilaku berwirausaha; (4) Thompson (2009) mendefinisikan bahwa niat berwirausaha sebagai keyakinan, persiapan serta komitmen untuk perencanaan berkelanjutan untuk mendirikan perusahaan baru. Dari definisi intensi berwirausaha yang sudah dijelaskan sebelumnya, dapat disimpulkan bahwa intensi berwirausaha adalah keinginan atau pengorbanan yang dilakukan seseorang untuk melakukan tindakan memulai usaha baru sehingga dapat mencapai tujuan tertentu. Beberapa ahli seperti Krueger (1993) dan Kolvereid (1996) telah menggunakan teori Ajzen tentang perilaku yang direncanakan untuk mengelompok kan pilihan pembentukan perusahaan dan telah membangun dukungan empiris dari teori di bidang kewirausahaan.

Ada beberapa teori untuk pendekatan niat berwirausaha diantaranya (1) teori acara kewirausahaan (Shapero dan Sokol, 1982); (2) perilaku terencana (Ajzen, 1991). Shapero dan Sokol (1982) menunjukkan bahwa niat untuk berwirausaha dipengaruhi oleh persepsi keinginan dan kemungkinan. Hubungan antara niat berwirausaha meliputi tiga aspek, yaitu (1) sikap terhadap kewirausahaan; (2) norma subjektif; (3) pengendalian yang dirasakan dari perilaku berwirausaha. Niat berwirausaha berperan penting untuk upaya penyelesaian dalam perilaku kewirausahaan (Fayolle et al., 
2006). Ada beberapa penelitian telah menemukan bahwa faktor pribadi terkuat yang mempengaruhi niat kewirausahaan digunakan untuk pencapaian, locus of control, dan kecenderungan pengambilan resiko (Brockhaus, 1982; Brockhaus dan Horwitz, 1986). Bruno dan Tyebjee (1982) telah menemukan bahwa ketersediaan sumber daya, pengaruh pemerintah, dan aksesibilitas pelanggan, pemasok dan transportasi menjadi prediksi akan niat berwirausaha dan ada juga yang menyatakan bahwa perpindahan pekerjaan, peluang kemajuan terbatas, frustrasi, kebijakan dan praktik manajemen, dan perubahan pasar juga telah ditemukan sebagai faktor motivasi yang kuat mengapa individu berniat untuk memulai bisnis mereka sendiri (Feinberg, 1984; Hisrish dan Bruss, 1985; Buther dan Moore, 1997; Dubini, 1989; Kickul dan Zaper, 2003).

Indikator intensi berwirausaha menurut Ajzen (1991) ada tiga, yaitu (1) Sikap merupakan suatu kondisi internal yang memengaruhi pilihan tindakan individu terhadap objek, orang atau kejadian tertentu. Sikap merupakan kecenderungan kognitif, afektif, dan tingkah laku yang dipelajari untuk merespon secara positif maupun negatif terhadap objek, situasi, institusi, konsep atau seseorang sikap terhadap perilaku yaitu sejauh mana seseorang berfikir seacara positif ketika melakukan perilaku tertentu dan ini mewakili hasil dari tingkat keinginan dan harapan; (2) norma subjektif mengacu pada tekanan sosial dan budaya untuk melakukan perilaku tertentu; (3) kontrol perilaku yang dirasakan merupakan kemampuan seseorang untuk mengukur perilaku.

\section{Rerangka Konseptual dan Hipotesi Penelitian}

Rerangka konseptual penelitian adalah suatu hubungan atau kaitan antara konsep satu terhadap konsep lainnya dari masalah yang akan diteliti. Berdasarkan hasil penelitian dari Lee et al. (2000) dan Darmawan (2016) yang menyatakan bahwa profesionalisme berpengaruh terhadap intensi berwirausaha dari karyawan maka hipotesis pertama di penelitian ini dapat dinyatakan sebagai berikut: profesionalisme berpengaruh positif signifikan terhadap intensi berwirausaha.

Penelitian dari Shaver dan Scott (1991); Babb and Babb (1992); Riipinen (1994); Koh (1996); Muller (2000); dan Mendol dan Marcus (2015) menyatakan bahwa motivasi berprestasi berpengaruh positif signifikan terhadap intensi berwirausaha karyawan. Dengan demikian berdasarkan temuantemuan tersebut dapat dinyatakan bahwa hipotesis kedua di penelitian ini adalah motivasi berprestasi berpengaruh terhadap intensi berwirausaha karyawan.

Penelitian dari Gbadamosi dan Nwosu (2011); Luca dan Simo (2016); dan Serinkan et al. (2013) menyatakan bahwa komitmen organisasi berpengaruh terhadap intensi berwirausaha karyawan. Dengan demikian hipotesis penelitian ketiga dinyatakan bahwa komitmen organisasi berpengaruh positif signifikan terhadap intensi berwirausaha karyawan.

Berdasarkan penjelasan sebelumnya maka rerangka konseptual dari variabel yang akan diteliti, yaitu pada Gambar 1 .

\section{METODE PENELITIAN}

Jenis penelitian ini termasuk penelitian survey karena penelitian yang menggunakan data dari sampel yang diambil dari populasi agar dapat melakukan generalisasi dari pengamatan. Populasi pada penelitian ini yaitu, seluruh karyawan yang bekerja di departemen keuangan. Teknik pengambilan sampelnya, yaitu dengan menggunakan teknik purposive sampling. Responden pada penelitian ini ada 100 responden yang ada di beberapa perusahaan di kota Surabaya, Sidoarjo, Gresik, Mojokerto dan Malang.

Penelitian ini melibatkan beberapa variabel, yaitu profesionalisme $\left(\mathrm{X} .1_{.1}\right)$, motivasi berprestasi $\left(\mathrm{X} .2_{2}\right)$, komitmen organisasi $\left(X_{.3}\right)$ dan intensi berwirausaha $(Y)$. Berikut ini definisi operasional variabel dan indikatornya. 


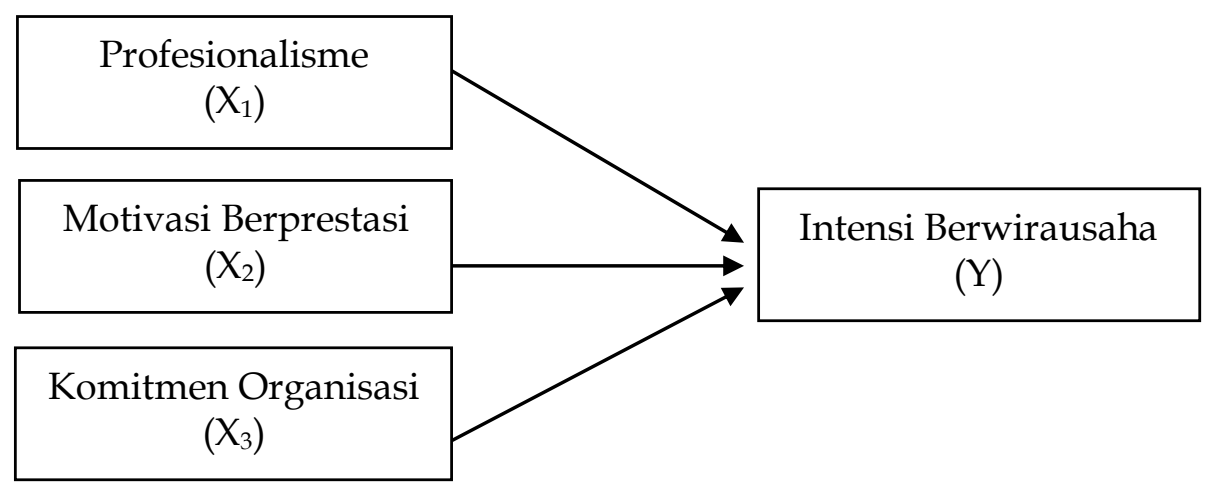

Gambar 1

Rerangka Konseptual Penelitian

a. Profesionalisme adalah sikap dan perilaku yang ditunjukkan oleh karyawan yang bekerja di departemen keuangan terhadap profesinya sebagai pengolah modal yang dapat memotivasi, bekerjasama dan beriteraksi secara profesional dengan rekan kerjanya (Hoyle, 1975; Boyt et al. 2001; Epstein dan Hundert 2002). Indikator profesionalisme ada lima, yaitu (1) pengabdian terhadap profesi; (2) kemandirian; (3) kewajiban sosial; (4) hubungan sesama profesi: dan (5) keyakinan terhadap profesi (Hall, 1968).

b. Motivasi berprestasi adalah dorongan atau keinginan karyawan yang bekerja di departemen keuangan untuk bekerja secara maksimal pada standar tertentu untuk mencapai kesuksesan dan menghindari kegagalan (Atkinson, 1964; Atkinson dan Feather 1966; Dave dan Anand 1979; Beigge dan Hunt 1980; Rabideau, 2005; Ghasemi et al., 2011; Weseley dan McEntarffer 2010). Indikator motivasi berprestasi ada empat, yaitu (1) penguasaan kebutuhan; (2) orientasi kerja; (3) kompetisi; dan (4) pribadi yang tidak peduli (Helmreich dan Spence, 1978).

c. Komitmen organisasi adalah kesediaan karyawan yang bekerja di departemen keuangan untuk membantu, memberikan kontribusinya dan tetap bertahan untuk mencapai tujuan perusahaan (Porter et al., 1974; Mowday et al., 1982;
Caught dan Shadur 2000; Miller dan Lee 2001; Miller, 2003; Swailes, 2002; Okpara, 2004; Fiorito et al., 2007; Wright dan Kehoe 2007). Indikator komitmen organisasi ada tiga, yaitu (1) komitmen afektif; (2) komitmen berkelanjutan; dan (3) komitmen normatif (Meyer dan Allen, 1997).

d. Intensi berwirausaha karyawan adalah keinginan atau pengorbanan yang dilakukan oleh karyawan yang bekerja di departemen keuangan untuk melakukan tindakan memulai usaha baru sehingga dapat mencapai tujuan tertentu (Shapero dan Sokol 1982; Krueger dan Brazeal 1994; Krueger, 1993; Wu et al., 2008; Thompson, 2009; Mobaraki dan Zare 2012;. Indikator intensi berwirausaha ada tiga, yaitu (1) sikap; (2) norma subjektif; dan (3) kontrol perilaku yang dirasakan (Ajzen, 1991).

Alat analisis di penelitian ini adalah analisis regresi linier berganda yang sebelumnya di uji validitas dan reliabilitas serta melalui uji asumsi klasik.

\section{ANALISIS DAN PEMBAHASAN Profil Responden}

Profil responden pada penelitian ini didasarkan pada jenis kelamin, usia, pendidikan terakhir dan masa kerja. Responden pada penelitian ini ada 100 dan rincian proporsi dari sebaran data responden dijelaskan pada Tabel 1 berikut ini. 
Tabel 1

Karakteristik Responden

\begin{tabular}{ccccc}
\hline \hline No & Karakteristik & Deskripsi & Frek. & \% \\
\hline 1 & Jenis Kelamin & Pria & 64 & $64 \%$ \\
& & Wanita & 36 & $36 \%$ \\
2 & Usia & $<30$ tahun & 59 & $59 \%$ \\
& & $30-39$ tahun & 24 & $24 \%$ \\
& & $40-49$ tahun & 10 & $10 \%$ \\
\multirow{3}{*}{3} & \multirow{3}{*}{ Pendidikan terakhir } & S0 tahun & 7 & $7 \%$ \\
& & SMA & 7 & $7 \%$ \\
& & D3 & 6 & $6 \%$ \\
& & S1 & 67 & $67 \%$ \\
4 & \multirow{3}{*}{ Masa Kerja } & S3 & 20 & $20 \%$ \\
& & $<1$ tahun & 13 & - \\
& & $1-4$ tahun & 46 & $46 \%$ \\
& & $5-10$ Tahun & 21 & $21 \%$ \\
& & $>10$ tahun & 20 & $20 \%$ \\
\hline
\end{tabular}

Sumber diolah dari hasil kuesioner

Dari Tabel 1 dapat diketahui bahwa responden dengan jenis kelamin pria ada 64 responden dan wanita ada 36 responden. Jenis kelamin seseorang mempengaruhi niat berkarir sebagai wirausaha (Verheul et al., 2012; Shinnar et al., 2012). Hal ini menunjukkan bahwa pria memiliki intensi berwirausaha yang lebih besar daripada wanita. Hal ini juga di dukung dengan penelitian dari (Scherer et al., 1989; Matthews dan Moser, 1995; Delmar dan Davidsson, 2000; Rodríguez dan Santos, 2008; Ventura dan Quero, 2013). Rentang usia karyawan yang bekerja di departemen keuangan terbanyak ada pada usia $<30$ tahun sebanyak 59 responden. Rentang usia tersebut menunjukkan bahwa karyawan yang bekerja di departemen keuangan didominasi oleh karyawan yang masih muda yang cenderung lebih produktif, sehingga memunculkan adanya potensi untuk intensi berwirausaha karena adanya keinginan untuk berkarir di usia muda. Menurut Lilez (1974) seseorang yang berusia antara 25-44 tahun akan mempunyai niat untuk berwirausaha. Hal ini juga sesuai dengan penelitian yang menyatakan bahwa ketika orang dewasa yang lebih muda dapat mengumpulkan modal, sosial dan keuangan melalui pekerjaan, pengalaman dan pendidikan, kemampuan mereka untuk berperilaku berwirausaha sangat kuat (Clarysse et al., 2011; Mayer-Haug et al., 2013). Reynolds et al. (2000) juga menyatakan bahwa seseorang yang berusia diantara 25-44 tahun adalah yang paling banyak berperan aktif untuk berwirausaha di Indonesia. Responden berdasarkan pendidikan terakhir di dominasi oleh S1 sebanyak 67 responden. Hal tersebut dapat dijadikan rekomendasi bahwa semakin tinggi pendidikan terakhir seseorang dapat menentukan adanya intensi berwirausaha. Hal ini sesuai dengan pernyataan bahwa tingkat pendidikan S1 atau S2 dapat mempengaruhi inovasi mereka (Becker, 1962) dan pengetahuan, keterampilan untuk berwirausaha (Schultz, 1961). Responden berdasarkan masa kerja didominasi oleh karyawan yang telah bekerja selama 1-4 tahun sebanyak 46 responden.

\section{Uji Validitas dan Reliabilitas}

Langkah yang ditempuh untuk menguji instrumen penelitian ini adalah dengan menggunakan uji validitas dan reliabilitas. 
Tabel 2

Uji Reliabilitas

\begin{tabular}{lc}
\hline \hline Variables & Alpha \\
\hline Profesionalisme (X.1) & 0.844 \\
Motivasi berprestasi (X.2) & 0.849 \\
Komitmen Org. (X.3) & 0.767 \\
Intensi Berwirausaha (Y) & 0.812 \\
\hline
\end{tabular}

Sumber diolah dari hasil kuesioner

Uji reliabilitas dinyatakan reliabel bila nilai koefisien Alpha > taraf signifikansi $60 \%$ atau 0,6 maka kuesioner tersebut reliabel dan bila koefisien Alpha < taraf signifikansi $60 \%$ atau 0,6 maka kuesioner tersebut tidak reliabel. Berdasarkan olah data melalui SPSS diketahui bahwa semua item pernyataan dari variabel profesionalisme $(X .1)$, motivasi berprestasi $\left(X_{.2}\right)$, komitmen organisasi $\left(X_{.3}\right)$ dan intensi berwirausaha $(\mathrm{Y})$ yang digunakan pada penelitian ini dapat dinyatakan valid dan dapat dipertanggungjawabkan serta dapat dipergunakan sebagai dasar pencari fakta.

Dari uji reliabilitas diketahui nilai cronbach's alpha lebih besar dari 0,6 seperti pada Tabel 2. Dengan demikian item-item pernyataan yang berhubungan dengan variabel intensi berwirausaha dinyatakan reliabel dan dapat digunakan untuk menganalisis data selanjutnya.

\section{Uji Asumsi klasik}

Sebelum melakukan analisis regresi linear berganda maka harus dilakukan uji asumsi klasik. Uji normalitas digunakan untuk menguji apakah pada model regresi, variabel terikat dan variabel bebas memiliki distribusi secara normal atau tidak. Distribusi normal akan membentuk garis lurus diagonal dan ploting data akan dibandingkan dengan garis normal. Gambar 2 menunjukkan bahwa titiktitik mengikuti garis diagonalnya.

Uji multikolinieritas dapat dilihat dari nilai tolerance dan nilai VIF. Jika nilai tolerance yang diperoleh kurang dari satu dan nilai VIF kurang dari sepuluh maka dapat dikatakan bahwa persamaan suatu model penelitian tidak menunjukkan adanya gejala multikolinieritas.

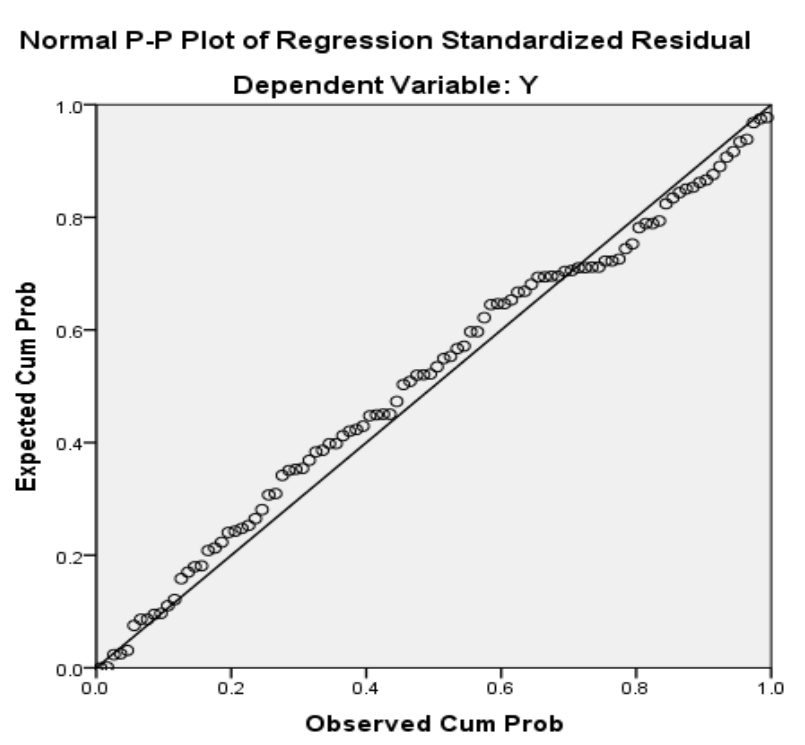

Gambar 2

Sumber : output SPSS

Normal Probability Plot

Tabel 3

Coefficients $^{a}$

\begin{tabular}{cccc}
\hline & Model & \multicolumn{2}{c}{ Collinearity } \\
& & Statistics \\
& & & \\
\hline 1 & (Colerance & VIF \\
\hline & X.1 & 0.109 & 9.173 \\
& X.2 & 0.112 & 8.963 \\
& X.3 & 0.168 & 5.957 \\
\hline
\end{tabular}

Sumber: output spss

Tabel 3 menunjukkan bahwa nilai tolerance dari masing-masing variabel bebas diperoleh nilai kurang dari satu dan nilai VIF kurang dari sepuluh. Dengan demikian persamaan model penelitian ini tidak menunjukkan gejala multikolinieritas.

Uji heteroskesdastisitas digunakan untuk menguji apakah model regresi terjadi ketidaksamaan variance dan residul satu pengamatan ke pengamatan yang lain. Salah satu cara untuk mendeteksi ada tidaknya heteroskesdastisitas pada suatu model persamaan regresi adalah dengan mengamati scatterplot pada dependent variable.

Gambar 3 menunjukkan bahwa titiktitik pada scatterrplot tersebar dan berada pada masing-masing bagian sumbu $Y$. Dengan demikian dapat disimpulkan bahwa tidak terjadi heteroskesdastisitas. 
Pengujian autokorelasi bertujuan untuk menguji apakah pada sebuah model regresi linear ada korelasi antara kesalahan penganggu pada periode $t$ dengan kesalahan penganggu pada periode $\mathrm{t}-1$ atau sebelumnya. Untuk mendeteksi ada atau tidaknya autokorelasi dapat dilihat dari nilai durbin watson. Berdasarkan output spss dapat disimpulkan bahwa tidak ada masalah pada uji autokorelasi. Hal ini dikarenakan nilai durbin watson menunjukkan 1,666 yang berarti diantara nilai positif dua dan negatif dua. Dengan demikian tidak ada masalah autokorelasi.

\section{Analisis Regresi Linear Berganda}

Untuk mengetahui pengaruh variabel bebas yang diteliti maka digunakan metode regresi linear berganda. Pada analisis regresi linear berganda akan dilakukan Uji t dan uji F. Berdasarkan hasil perhitungan dengan menggunakan SPSS diperoleh hasil seperti pada Tabel 4 sebagai berikut.

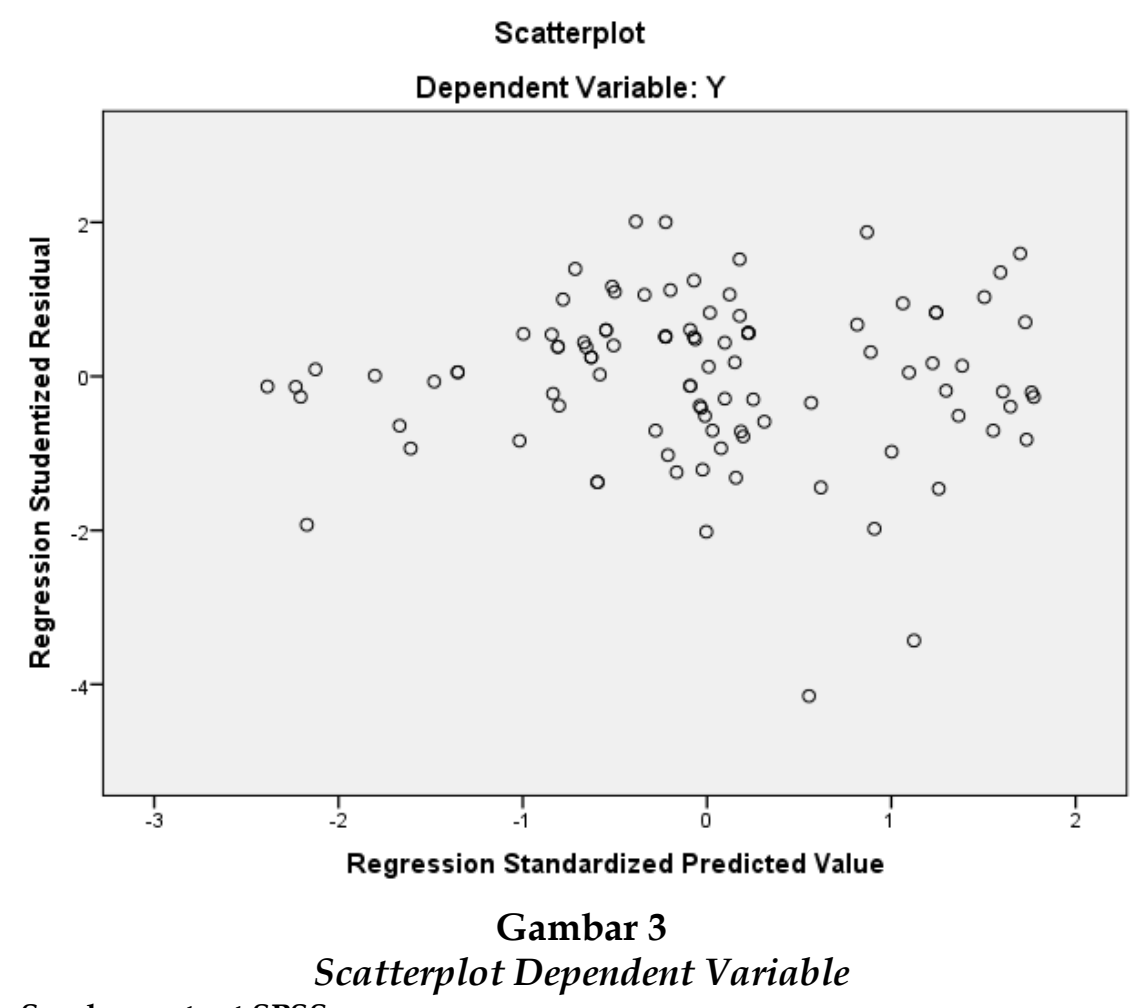

Sumber: output SPSS

Tabel 4

Coefficients ${ }^{a}$

\begin{tabular}{cccccc}
\hline Model & \multicolumn{2}{c}{$\begin{array}{c}\text { Unstandardized } \\
\text { Coefficients }\end{array}$} & $\begin{array}{c}\text { Standardized } \\
\text { Coefficients }\end{array}$ & T & Sig \\
\cline { 2 - 4 } & B & Std Error & Beta & & \\
\hline (Constant) & 4.673 & 1.388 & & 3.367 & 0.001 \\
$X_{1}$ & 0.482 & 0.064 & 0.472 & 7.497 & 0.000 \\
X $_{2}$ & 0.308 & 0.060 & 0.318 & 5.114 & 0.000 \\
X $_{3}$ & 0.262 & 0.061 & 0.217 & 4.285 & 0.000 \\
\hline
\end{tabular}

Sumber: output spss

Dari hasil perhitungan Tabel 4 model persamaan regresi linear yang dihasilkan adalah $Y=4,673+0,482\left(X_{.1}\right)+0,308\left(X_{.2}\right)+$ $0,262\left(X_{.3}\right)$.Selanjutnya dari hasi perhitungan 
Tabel 4 model persamaan regresi linear berganda sebelumnya menunjukkan bahwa ada pengaruh antara intensi berwirausaha karyawan $(\mathrm{Y})$ sebagai variabel terikat dari variabel profesionalisme $\left(X_{.1}\right)$, motivasi berprestasi $\left(X_{.2}\right)$, komitmen organisasi $\left(X_{.3}\right)$ sebagai variabel bebas. Pengaruh tersebut menunjukkan bahwa variabel profesionalisme, motivasi berprestasi dan komitmen organisasi sebagai variabel bebas berubah searah dengan perubahan intensi berwirausaha sebagai variabel terikat.

Selanjutnya untuk melihat pengaruh masing-masing variabel bebas terhadap variabel terikat dilakukan dengan $\mathrm{Uji}$ t. Kemudian untuk mengetahui apakah variabel bebas profesionalisme, motivasi berprestasi, komitmen organisasi secara bersama-sama mempengaruhi intensi berwirausaha dapat dilakukan Uji F. Uji $t$ dapat dilihat dari Tabel 4 dan nilai $\mathrm{t}$ hitung harus lebih kecil dari a $=0,05$ atau lebih kecil dari taraf nyata 5\%. Dari Tabel 4 dapat dijelaskan bahwa variabel intensi berwirausaha karyawan terus meningkat sebesar 4,673 seriring dengan semakin terpenuhinya probabilitas profesionalisme $\left(X_{.1}\right)$ sebesar 0,000 ; motivasi berprestasi $\left(X_{.2}\right)$ sebesar 0,000 ; komitmen organisasi $\left(X_{.3}\right)$ sebesar 0,000 . Hal ini berarti bahwa variabel bebas yaitu profesionalisme $(X .1)$, motivasi berprestasi $\left(X_{.2}\right)$, komitmen organisasi (X.3) pada taraf nyata $(5 \%)$ mempunyai pengaruh yang bermakna terhadap intensi berwirausaha. Bila dilihat dari nilai koefisien regresi tertinggi di antara variabel bebas maka yang memiliki nilai koefisien regresi tertinggi adalah variabel profesionalisme $\left(X_{.1}\right)$ sebesar 0,482 dengan probabilitas 0,000 dibandingkan dengan variabel motivasi berprestasi $\left(X_{.2}\right)$ sebesar 0,308 dengan probabilitas 0,000; komitmen organisasi $\left(X_{.3}\right)$ sebesar 0,262 dengan probabilitas 0,000. Untuk lebih jelasnya akan diuraikan hasil pengujian masing-masing variabel bebas terhadap variabel terikat sebagaimana berikut ini.

1. Pengaruh profesionalisme $\left(X_{.1}\right)$ terhadap intensi berwirausaha. Koefisien regresi variabel X.1 adalah sebesar 0,482. Hal ini menunjukkan hubungan positif atau searah dengan intensi berwirausaha, artinya bila profesionalisme ditunjukkan dengan baik oleh karyawan terhadap perusahaan maka intensi berwirausaha karyawan akan meningkat. Nilai t hitung untuk variabel profesionalisme sebesar 7,497 dengan probabilitas 0,000. Hal ini menunjukkan bahwa pengaruh profesionalisme $\left(X_{.1}\right)$ terhadap intensi berwirausaha $(\mathrm{Y})$ adalah signifikan.

2. Pengaruh motivasi berprestasi (X.2) terhadap intensi berwirausaha. Koefisien regresi variabel $X_{.2}$ adalah sebesar 0,308. Hal ini menunjukkan hubungan positif atau searah dengan intensi berwirausaha, artinya bila motivasi berprestasi ditunjukkan dengan maksimal oleh karyawan terhadap perusahaan maka intensi berwirausaha akan meningkat. Nilai $t$ hitung untuk variabel motivasi berprestasi sebesar 5,114 dengan probabilitas 0,000 . Hal ini menunjukkan bahwa pengaruh motivasi berprestasi (X.2) terhadap intensi berwirausaha $(\mathrm{Y})$ adalah signifikan.

3. Pengaruh komitmen organisasi (X.3) terhadap intensi berwirausaha. Koefisien regresi variabel $X_{.3}$ adalah sebesar 0,262. Hal ini menunjukkan hubungan positif atau searah dengan intensi berwirausaha, artinya bila komitmen organisasi ditunjukkan dengan maksimal oleh karyawan terhadap perusahaan maka intensi berwirausaha karyawan akan meningkat. Nilai $t$ hitung untuk variabel komitmen organisasi sebesar 4,285 dengan probabilitas 0,000 . Hal ini menunjukkan bahwa pengaruh komitmen organisasi (X.3) terhadap intensi berwirausaha $(Y)$ adalah signifikan.

Uji $\mathrm{F}$ digunakan untuk mengetahui apakah variabel bebas yang diteliti profesionalisme $\left(X_{.1}\right)$, motivasi berprestasi $\left(X_{.2}\right)$, komitmen organisasi $\left(X_{.3}\right)$ secara simultan berpengaruh terhadap intensi berwirausaha (Y). Penjelasan tersebut dapat dilihat dari Tabel 5. 
Tabel 5

ANOVA ${ }^{a}$

\begin{tabular}{lccccc}
\hline \hline & Sum of Square & df & Mean Square & F & Sig \\
\hline Regression & 4228.976 & 3 & 1409.659 & 740.571 & $0.000 \mathrm{~b}$ \\
Residual & 182.734 & 96 & 1.903 & & \\
Total & 4411.710 & 99 & & & \\
\hline
\end{tabular}

Sumber: output spss

Uji $\mathrm{F}$ dilakukan dari hasil perhitungan Tabel 5 dapat dilihat bahwa nilai $\mathrm{F}$ hitung sebesar 740,571 dengan probabilitas 0,000, hal ini berarti bahwa pada taraf nyata $a=$ 0,05 dapat dikatakan bahwa variabel profesionalisme, motivasi berprestasi, komitmen organisasi mempunyai pengaruh yang berarti terhadap intensi berwirausaha .

Koefisien determinasi mengukur sejauh mana peranan variabel bebas terhadap variabel terikat. Koefisien determinasi berfungsi sebagai ukuran ketepatan atau kecocokan suatu jenis regresi terhadap kelompok data hasil observasi $\mathrm{R}^{2}$ mengukur proporsi atau presentasi total variasi dalam Y yang dijelaskan oleh model regresi koefisien determinasi dari 0 sampai 1 dan apabila mendekati 1 maka semakin baik.

\section{Tabel 6}

Model Summary ${ }^{b}$

\begin{tabular}{cccll}
\hline \hline $\mathbf{R}$ & $\begin{array}{c}\mathbf{R} \\
\text { Square }\end{array}$ & $\begin{array}{c}\text { Adjusted } \\
\text { R Square }\end{array}$ & $\begin{array}{c}\text { Std Error } \\
\text { of the } \\
\text { Estimate }\end{array}$ & $\begin{array}{c}\text { Durbin } \\
\text { Watson }\end{array}$ \\
\hline $0.979 \alpha$ & 0.959 & 0.957 & 1.380 & 1.666 \\
\hline Sumber: output spss & & & \\
\hline
\end{tabular}

Berdasarkan pada hasil penghitungan Tabel 6 koefisien R sebesar 0,979 menunjukkan ada hubungan yang cukup kuat antara variabel bebas dengan variabel terikat. Koefisien determinan $\left(R^{2}\right)$ sebesar 0,959 dan adjusted $R$ squared sebesar 0,957 menunjukkan bahwa model regresi berganda ini yang variabel bebasnya terdiri dari profesionalisme $\left(X_{1}\right)$, motivasi berprestasi $\left(X_{2}\right)$, komitmen organisasi $\left(X_{3}\right)$ telah memberikan kontribusi sebesar $95,9 \%$ terhadap pembentukan variabel terikat yaitu intensi berwirausaha, sedangkan sisanya sebesar 4,1\% ditentukan oleh variabel yang lain.

\section{Analisis dan Pembahasan}

Berdasarkan hasil yang didapatkan dari jawaban responden melalui kuesioner yang disebarkan dan hasil analisis regresi linear berganda sebelumnya dapat diperoleh bahwa variabel yang mempengaruhi intensi berwirausaha adalah profesionalisme, motivasi berprestasi, komitmen organisasi.

Hasil penelitian berdasarkan pembuktian hipotesis pertama menunjukkan bahwa profesionalisme berpengaruh positif signifikan terhadap intensi berwirausaha. (Lee et al., 2000; Darmawan, 2016). Salah satu komponen dari profesionalime adalah adanya sikap kemandirian. Sikap kemandirian merupakan dukungan batin dari tindakan seseorang, perasaan berasal dari diri sendiri dan merupakan milik sendiri (Deci dan Ryan, 2000). Kepribadian berhubungan dengan upaya menuju pengembangan dan realisasi tujuan, nilai, niat, minat pribadi (Assor et al., 2002). Upaya pengembangan dan realisasi tujuan seseorang dapat berbentuk dengan adanya intensi untuk berwirausaha. Pihak Manajemen dapat menerapkan (1) sistem mentoring yang berarti berbagi pengalaman dan pengetahuan. Mentoring dan realisasi tujuan nasib sendiri berperan penting untuk pengembangan niat berwirausaha. Mentor kewirausahaan harus secara khusus mendukung karyawannya untuk mengembangkan kemampuan untuk bertindak secara mandiri sebagai konsep kompetensi berwirausaha; (2) efektifitas dari mentor kewirausahaan bervarasi sesuai dengan status pekerjaan dan negara, hal ini sangat 
penting untuk mencapai target dan merancang intervensi mentor kewirausahaan; (3) mendukung karyawan yang memiliki sikap kemandirian yang rendah agar menghargai dan mengembangkan kemampuannya (Baluku et al., 2019).

Hasil penelitian berdasarkan pembuktian hipotesis kedua menunjukkan bahwa motivasi berprestasi berpengaruh positif signifikan terhadap intensi berwirausaha karyawan. (Shaver dan Scott, 1991; Babb and Babb, 1992; Riipinen, 1994; Koh, 1996; Muller, 2000; Mendol dan Marcus, 2015).

Hal ini menunjukkan bahwa semakin tinggi motivasi berprestasi yang dimiliki maka intensi untuk berwirusaha juga besar. Pihak manajemen dapat menerapkan (1) inovasi, inovasi sebagai proses untuk menciptakan, mengubah dan berkembang. Menurut Schumpeter (1934) inovasi merupakan komponen penting dari karakteristik kewirauasahaan sehingga dapat mempengaruhi intensi berwirausaha; (2) pengambilan resiko, mengambil resiko dianggap sebagai karakteristik seorang wirausaha (Teoh dan Foo, 1997; Yurtkoru et al., 2014), ketika seorang wirausaha mengambil resiko maka akan berhubungan dengan antusiasme untuk tindakan yang berani seperti memasuki pasar atau peluang baru yang tidak ditentukan, menginvestasikan uang dengan jumlah yang besar yang memiliki lebih banyak peluang kegagalan atau hasil yang tidak pasti; (3) locus of control, seseorang mempercayai bahwa kejadian dalam hidupnya dipengaruhi oleh keberuntungan atau nasib ((Riipinen, 1994; Koh, 1996; McGee dan McGee, 2016) dan Mitton (1989) juga mengemukakan bahwa sifat ini berhubungan dengan persepsi individu yang memiliki kemampuan untuk mengendalikan kesempatan hidup mereka sendiri. Mueller dan Thomas (2000) menyatakan bahwa wirausahawan memiliki lebih banyak lokus pengendalian internal dibandingkan dengan yang lain dan menemukan hubungan positif dengan aspirasi untuk menjadi wirausaha.

Hasil penelitian berdasarkan pembuktian hipotesis ketiga menunjukkan bahwa komitmen organisasi berpengaruh positif signifikan terhadap intensi berwirausaha (Gbadamosi dan Nwosu, 2011; Luca dan Simo, 2016; Serinkan et al., 2013). Hal ini menunjukkan bahwa karyawan akan bersedia berkomitmen dengan organisasi apabila mereka merasa puas dengan pekerjaannya. Pihak manajemen harus dapat membuat karyawan merasa puas dengan pekerjaannya dan hasil penelitian menunjukkan bahwa ada hubungan yang kuat antara kepuasan kerja terhadap komitmen organisasi (Ayeni dan Phopoola, 2007; Gunlu et al., 2009) ketika karyawan tidak puas dengan pekerjaan mereka maka karyawan merasa mendapatkan tekanan psikologis dan ketidakadilan yang dirasakan di tempat kerja sehingga akan ada kecenderungan ingin pergi dan tidak berkomitmen pada organisasi serta berniat untuk memulai usaha. Di organisasi besar niat berwirausaha karyawan dinilai sebagai perilaku dari karyawan yang menguntungkan karena dapat meningkatkan daya saing dan kinerja karyawan.

\section{SIMPULAN DAN SARAN Simpulan}

Berdasarkan hasil analisis dan pembahasan maka simpulan dari hasil penelitian ini, yaitu; Pertama, profesionalisme berpengaruh positif signifikan terhadap intensi berwirausaha; Kedua, motivasi berprestasi berpengaruh positif signifikan terhadap intensi berwirausaha; Ketiga, komitmen organisasi berpengaruh positif signifikan terhadap intensi berwirausaha.

\section{Saran}

Berdasarkan hasil analisis, pembahasan dan simpulan sebelumnya maka saran yang dapat diberikan oleh peneliti, yaitu; Pertama untuk mencapai tingkat profesionalisme yang tinggi dari karyawan, perusahaan harus dapat menempatkan karyawan yang sesuai dengan profesinya yang dapat dilihat dari (pengetahuan, kemampuan, bakat dan minat yang dimiliki), hal ini bertujuan apabila karyawan bekerja sesuai dengan profesinya maka perilaku karyawan dapat dikatakan baik. 
Perusahaan juga dapat memberikan edukasi kepada karyawan bahwa sikap profesionalisme karyawan dapat ditingkatkan dengan adanya (1) sikap bertanggung jawab, yang berarti karyawan dapat bertanggung jawab dengan keputusan dan konsekuensi yang baik atau buruk di tempat mereka bekerja, mengakui kesalahan dan bersedia belajar; (2) karyawan bekerja melebihi harapan perusahaan, hal tersebut dapat dilakukan dengan adanya pelatihan soft skill sehingga dapat mendorong dan mengembangkan potensi karyawan; (3) bersikap etis, perusahaan memberikan kode etik yang jelas kepada karyawan karena menetapkan standar etika yang tinggi dari perusahaan diharapkan dapat menjadikan karyawan bekerja secara profesional dan memiliki peluang untuk sukses; (4) karyawan harus mengetahui bagaimana berkomunikasi dengan baik, hal ini juga dapat di dukung dengan membantu karyawan mengembangkan keterampilan berkomunikasi melalui pelatihan khusus yang betujuan untuk membantu karyawan berkomunikasi dengan kolega; Kedua, motivasi berprestasi karyawan dapat juga ditingkatkan dengan upaya (1) pemberian reward, reward yang diberikan oleh perusahaan dapat berupa kesempatan pengembangan diri karyawan, adanya pengakuan dan pujian serta kesempatan mempromosikan diri yang diberikan perusahaan kepada karyawan; (2) pemberian insentif, pencapaian tertinggi dari karyawan yang bekerja keras maka akan dihargai secara financial dan kebijakan yang menawarkan insentif sebagai imbalan dari prestasi dapat memotivasi semua karyawan untuk meningkatkan dan membuktikan prestasi mereka; (3) suasana tempat kerja yang kondusif, karyawan akan termotivasi dengan suasana tempat kerja yang karyawannya saling menghargai dan menghormati. Hal tersebut dapat memotivasi karyawan untuk menunjukkan prestasinya di perusahaan yang dapat melebihi visi dan misi perusahaan; (4) manajer harus memotivasi karyawan untuk bekerja lebih baik dari waktu ke waktu dan hal tersebut juga didukung dengan strategi berupa imbalan yang dapat diberikan perusahaan untuk memenuhi kebutuhan karyawan dan apabila kebutuhan karyawan dapat terpenuhi maka motivasi untuk berprestasi juga tinggi; dan Ketiga, komitmen organisasi dapat ditingkatkan melalui (1) pengembangan karir karyawan dapat dimulai dengan memiliki program formal seperti seminar atau workshop yang ditujukan agar karyawan dapat berkembang di dalam atau luar organisasi; (2) memiliki program pemberian kebijakan seperti mengurangi tingkat keluar masuknya karyawan; (3) menjaga hubungan baik antara manajer dan karyawan sehingga keberadaan karyawan merasa dihargai oleh perusahaan; (3) memberikan penilaian kinerja secara adil kepada karyawan.

\section{DAFTAR PUSTAKA}

Ajzen, I. 1991. "The Theory of Planned Behaviour." Organizational Behaviour and Human Decision Processes 50(2): 179-211.

Altinay, L., Madanoglu, M., Daniele, dan R. Lashley, C. 2012. “The Influence of Family Tradition and Psychological Traits on Entrepreneurial Intention." International Journal of Hospitality Management 31(2): 489-499.

Assor, A., Kaplan, H., dan Roth, G. 2002. "Choice is Good, but Relevance is Excellent: Autonomy-Enhancing and Suppressing Teacher Behaviors Predicting Students' Engagement in schoolwork." British Journal of Educational Psychology, 72: 261-278.

Atkinson, J. W. and Feather, N. T. 1966. A Theory of Achievement Motivation. Wiley. New York.

Ayeni, C. O., dan Phopoola, S. O. 2007. “Work Motivation, Job Satisfaction, and Organizational Commitment of Library Personnel in Academic and Research Libraries in Oyo state." Nigeria, Library Philosophy and Practice: 366-376.

Azhar, A., Javaid, A., Rehman, M., dan Hyder, A. 2010. "Entrepreneurial Intentions Among Business Students in Pakistan." Journal of Business Systems, Governance dan Ethics 5(2): 13-21. 
B'echard, J. P., dan Gr'egoire, D. 2005. "Entrepreneurship Education Research Revisited: The Case of Higher Education." Academy of Management Learning dan Education 4(1): 22-43.

Babb, E. M., dan Babb, S. V. 1992. "Psychological Traits of Rural Entrepreneurs". The Journal of Socio-Economics 21: 353-362

Baluku, M. B, Matagi Leonsio, E. Bantu dan K. Otto. 2009. "The Impact of Autinimy on the Relationship Betweeen Mentoring and Entrepreneurial Intentions Among Youth in Germany, Kenya and Uganda." International Journal of Entrepreneurial Behavior and Reserach 25(2): 170-192.

Becker G. 1962. "Investment in Human Capital: a theoretical analysis." Journal of Political Economy 70): 9-44.

Biegge, M. O., dan Hunt, Y. B. 1980. "Intrapersonal and Interpersonal Theories of Motivation from an Attributional Perspective." Educational Psychology Review, 12(1): 1-14.

Bird, B. dan Jelinek, M. 1988. "The Operation of Entrepreneurial Intentions." Entrepreneurship Theory and Practice 13: 21-29.

Boyt, T. E., Lusch, R. F., dan Naylor, G. 2001. "The Role of Professionalism in Determining Job Satisfaction in Professional Services: a study of marketing researchers." Journal of Service Research 3(4): 321-330.

Brockhaus, R. H. 1982. Psychology of the Entrepreneur. In D. L. Sexton

Brockhaus, R. H., dan Horwitz, P. S. 1986. “The Psychology of the Entrepreneur. In D. Sexton dan R. L. Smilor (Eds.), The art and science of entrepreneurship (39-57). England Cliffs, N.J; Prentice Hall.

Bruno, A. V., dan Tyebjee, T.,T. 1982. "The Environment of Entrepreneurship." Academy of Management Journal. 23(3): 509-520.

Burrage, M., Torstendahl, R. 1990. "Professions in Theory and History: Rethinking the Study of the Professions, Sage Publications, London. Business Management 24: 1-8.

Buttner, H., dan Moore, D. 1997. “Women's Organizational Exodus to Entrepreneurship; Self-Reported Motivations and
Correlates with Success." Journal of Small Business Management 35(1): $34-46$.

Bygrave, W., dan Hofer, C. 1991. "Theorizing about Entrepreneurship." Entrepreneurship Theory and Practice 16(2): 13-22.

Caught, K., dan Shadur. 2000. “The Measurement Artifact in the Organizational Commitment Questionnaire." Psychological Reports 87: 777-788.

Chabaud, D., and J. Ngijol. 2004. "The Recognition of Market Opportunities by Entrepreneurs: Towards a Constructivist Perspective." In 17th Annual Research Symposium on Marketing and Entrepreneurship. Chicago: University of Illinois.

Clarysse, B., Tartari, V., dan Salter, A. 2011. "The Impact of Entrepreneurial Capacity, Experience and Organizational Support on Academic Entrepreneurship." Research Policy 40(8): 1084-1093.

Darmawan, didit. 2016. "Pengaruh Keterlibatan Kerja dan Sikap profesionalisme Terhadap Intensi Berwirausaha Karyawan." Global 1(1): 22-29.

Dave, P. N. dan Anand, C. L. 1979. Correlates of Achievement: a trend report, in M. B. Buch (Ed.). Second survey of research in education, SERD, Baroda.

Deci, Edward L. dan M. Ryan. 2000. "SelfDetermination Theory and the Facilitation of Intrinsic Motivation, Social Development, and Well-Being Richard." Psychological Association 55(1): 68-78.

Delmar, F., dan Davidsson, P. 2000. “Where do They Come From? Prevalence and Characteristics of Nascent Entrepreneurs." Entrepreneurship and Regional Development 12(1): 1-23.

DÍaz-Garcĺa, M.C, Jimenez-Moreno, J. 2006. "Entrepreneurial intention: The role of Gender." International Entrepreneurship and Management Journal 6(3): 261-283.

Dickson, P. H., Solomon, G. T. and Weaver, K.M. 2008. "Entrepreneurial Selection and Success: does education matter?." Journal of Small Business and Enterprise Development 15(2): 239-258.

Dinis, A., Ferreira, J., Paco, Arminda., Raposo, Mario., dan Rodrigues, R.G. 2013. 
"Psychological Characteristics and Entrepreneurial Intentions among Secondary Students". Education and Training 55(8-9): 763-780.

Dubini, P. 1989. “The influence of Motivations and Environment on Business Start-Ups: Some Hints for Public Policies." Journal of Business Venturing 1(11-26): 7-22.

Eckhardt, J. T. dan Shane, S. A. 2003. "Opportunities and Entrepreneurship." Journal of Management 29(3): 333-349.

Epstein, R. M., dan Hundert, E. M. 2002. "Defining and Assessing Professional Competence." Journal of the American Medical Association 287(2): 226-235.

Eslami, J., dan Gharakhani, D. 2012. "Organizational Commitment and Job Satisfaction." ARPN Journal of Science and Technology 2(2): 85-91.

Fayolle, A., Gailly, B., dan Lassa-Clerc, N. 2006. "Assessing the Impact of Entrepreneurship Education Programmes: a new methodology." Journal of European Industrial Training 30(9): 701-720.

Feinberg, A. 1984. "Inside the Entrepreneur." Venture 6(5): 80-85.

Ferreira, J. J., Raposo, A., dan Paço, A. 2012. “A Model of Entrepreneurial Intention: An Application of the Psychological and Behavioral Approaches." Journal of Small Business and Enterprise Development 19(3): 424-440.

Fiorito, J., Bozeman, D. P., Young, A., dan Meurs, J. A. 2007. “Organizational Commitment, Human Resource Practices, and Organisational Characteristics." Journal of Managerial Issues 19(2): 186-207.

Gbadamosi, L. dan Nwosu C. 2011. Organizational Politics, Turnover Intention and Organizational Commitment as Predictors of Employees' Efficiency and Effectiveness in Academia.

Ghasemi, F., Rastegar, A., Jahromi, R. G., dan Marvdashti, R. R. 2011. “The Relationship Between Creativity and Achievement Motivation with High school Students' Entrepreneurship." Social and Behavioral Sciences 30:1291-1296.
Gunlu, E., Aksarayli, M., dan Percin, N. S. 2009. "Job Satisfaction and Organizational Commitment of Hotel Managers in Turkey." International Journal of Contemporary Hospitality Management 22(5): 693717.

Helmreich, R. L., dan Spence, J. T. 1978. “The Work and Family Orientation Questionnaire: An objective instrument to assess components of achievement motivation and attitudes toward family and career." Journal Supplement Abstract Service, Catalog of Selected Documents in Psychology, 8:35.

Hisrich, R. D., and Brush, C. 1986. Women and Minority Entrepreneurs: A Comparative Analysis. Frontiers of Entrepreneurship Research. Ed. John

Holland, J. L. 1985. Making vocational choices. Englewood Cliffs, NJ: Prentice Hall.

Hoyle, E. 1975. "Professionality, Professionalism and Control in Teaching. In V. HOUGHTON et al. (eds) Management in Education: the Management of Organisations and Individuals, Ward Lock Educational in association with Open University Press. London.

Jemielniak, D. 2005. "Kultura: Zawody i profesje", in: Prace i Materiaty ISM (Instytut Studiów Międzynarodowych), No. 32, O ficyna Wydawnicza SGH, Warszawa.

Kanter, R. M. 1989. Careers and the Wealth of Nations: A Macro-Perspective on the Structure and Implications of Career forms. In M. Arthur, D. Hall, B. Lawrence (Eds.), Handbook of career theory, Cambridge University Press, Cambridge, UK, 506-522.

Keat, O. Y., Selvarajah, C., dan Meyer, D. 2011. "Inclination Towards Entrepreneurship Among University Students: An Empirical Study of Malaysian University Students." International Journal of Business and Social Science. 2: 4.

Kickul, J., dan Zaper, J. 2000. “Untying the knot: Do Personal and Organizational Determinants Influence Entrepreneurial Intentions?." Journal of Small Business and Entrepreneurship. 15(3): 57-77. 
Koh, H. C. 1996. "Testing Hypotheses of Entrepreneurial Characteristics: A study of Hong Kong MBA Students." Journal of Managerial Psychology 11(3): 1225.

Kolveried, L. 1996. “Organizational Employment Versus Self-Employment: reasons for career choice intentions." Entrepreneurship Theory dan Practice 20(3): 23-31.

Krueger, N. F. dan Brazeal, D. V. 1994. "Entrepreneurial Potential and Potential Entrepreneurs." Entrepreneurship Theory and Practice 18(3): 91-104.

Krueger, N. F. 1993. "Entrepreneurial Intentions: Applying the Theory of Planned Behaviour." Entrepreneurship dan Regional Development 5(4): 315-330.

Lee A.G., Beaver H. A., Boldt H.C., Olson R., Oetting T.A., Abramoff M., Carter K. 2007. "Teaching and Assessing Professionalism in Ophthalmology Residency Training Programs." Surv. Ophthalmol 52(3): 300314.

Legge, K.1995. Human resource management. London, MacMillan Press. England.

Luca, M. R dan A. M Simo. 2011. "Entepreneurial Traits and Work Satisfaction." Bulletin of the Transilvania University of Braşov. 9:58, Special Issue Series VII, Social Sciences Law, No. 1 - 2016.

Madrigal, B., Arechavala, R., dan Madrigal, R. 2012. "Elemprendedor y su capital social: caso el cl'uster del software en jalisco." Revista Internacional Administracion dan Finanzas 5(4): 107-120.

Maes, J., Leroy, H., dan Sels, L. 2014. “Gender Differences in Entrepreneurial Intentions: A TPB Multi-Group Analysis at Factor and Indicator Level." European Management Journal 32(5): 784-794.

Mathieu, J. E., dan Zajac, D. M. 1990. A Review and Meta-Analysis of the Antecedents, Correlates, and Consequences of Organizational Commitment. Psychological Bulletin 108(2): 171-194.

Matthews, C. H., dan Moser, S. B. 1995. "Family Background and Gender: Implications for Interest in Small Firm Ownership." Entrepreneurship and Regional Development 7(4): 365377.
Mayer-Haug, K., Read, S., Brinckmann, J., Dew, N., dan Grichnik, D. 2013. "Entrepreneurial Talent and Venture Performance: A meta-analytic investigation of SMEs." Research Policy 42(6 -7): 1251-1273.

McClelland, D. C. 1953. The Achievement Motive. Appleton-Century-Crofts. New York.

McClelland, D. C. 1961. The Achieving Society. Appleton-Century-Crofts, New York, NY.

McGee, Andrew and Peter McGee. 2016. "Search, Effort, and Locus of Control." Journal of Economic Behavior and Organization 126: 89-101.

Mendol, P. C., dan Marcus. 2015. “A Pattern Analysis of Students' Achievement Goals." Journal of Educational Psychology, 85(4): 582-590.

Meyer, J. P., dan Allen, N. J. 1987. Organi zational Commitment: Toward a Threecomponent Model. London: The University of Western Ontario, Department of Psychology.

Meyer J, Becker T dan Van Dick R. 2006. "Social Identities and Commitments at Work: Toward an Integrative Model", Journal of Organizational Behavior 27: 665683.

Meyer, J. P., dan Herscovitch, L. 2001. "Commitment in the Workplace: Toward a General Model." Human Resource Management Review 11(3): 299-326.

Miller, G. A. 2003. "The Cognitive Revolution: A historical perspective." Trends in Cognitive Sciences 7(3): 141-144.

Mitton, D. G. 1989. "The Complete Entrepreneur". Entrepreneurship: Theory and Practice, 13: 9-19.

Mowday, R. T., Porter, L. W., dan Steers, R. M. 1982. Employee-Organization Linkages: The Psychology of Commitment, Absenteeism, and Turnover. Academic Press. New York, NY.

Mowday, R. T., Steers, R. M., dan Porter, L. W. 1979. "The Measurement of Organizational Commitment." Journal of Vocational Behavior 14(2): 224-247.

Müller, S. 2008. Encouraging Future Entrepreneurs: The Effect of Entrepreneurship Course Characteristics on Entrepreneurial 
Intention. University of St.Gallen, St.Gallen

Mumtaz, B. A. K, Munirah, S., dan Halimahton, K. 2012. “The Relationship Between Educational Support and Entrepreneurial Intentions in Malaysian Higher Learning Institution." Procedia Social and Behavioral Sciences 69(24): 21642173.

Nanda, R. and J. B. Sorensen. 2006. "Peer Effects and Entrepreneurship." Retrieved May 31, 2000.

Okpara, J. O. 2004. "Job satisfaction and organizational commitment: Are there differences between American and Nigerian Managers employed in the US MNCs in Nigeria? Academy of Business and Administrative Science, Briarcliffe College, Switzerland.

Pintrich P. R., dan Schunk D. H. 1996. Motivation in Education: Theory, Research and Applications, Prentice Hall. Englewood Cliffs, NJ.

Porter, L. W., Steers, R. M., Mowday, R. T., dan Boulian, P. V. 1974. “Organizational Commitment, Job Satisfaction, and Turnover Among Psychiatric Technicians." Journal of Applied Psychology 59(5): 603-609.

Rabideau, S. T. 2005. Eflects of achievement motivation on behavior. Retrieved May 7, 2016, from personality research: http:// www.personalityresearchorg.

Reynolds, P. D., Hay, M., Bygrave, W. D., Camp, S. M. dan Autio, E. 2000. Global Entrepreneurship Monitor: 2000 Executive Report. Kauffman Center for Entrepreneurial Leadership. Kansas City.

Riipinen, M. 1994. "Extrinsic Occupational Needs and the Relationship Between Need for Achievement and Locus of Control." The Journal of Psychology 128(5): 577-88.

Robinson, P. B., Huefner, J. C., dan Hunt, H. K. 1991. "An Attitude Approach to the Prediction of Entrepreneurship." Entrepreneurship Theory and Practice 15(4): 13-32.

Rodriguez, M. J, Santos, F. J. 2008. “La Actividad Emprendedora de las Mujeres y el Proceso de Creación de Empresas." Información Comercial Española 841:117-132.
Sandhu, M. S, Sidique, S. F. dan Riaz, S. 2011. "Entrepreneurship Barriers and Entrepreneurial Inclination Among Malaysian Postgraduate Students." International Journal of Entrepreneurial Behaviour and Research 17(4): 428-449.

Scherer, R. F., J. S. Adams, S. S. Carley dan F.A. Wiebe. 1989. "Role Model Performance Effects on Development of Entrepreneurial Career Preference." Entrepreneurship Theory and Practice, Spring: 53-71.

Schultz, T. W. 1961. "Investment in Human Capital." The American Economic Review, 51(1): 1-17.

Schumpeter, J. A. 1934. The Theory of Economic Development: An inquiry into profits, capital, credit, interest, and the business cycle. Harvard University Press. Cambridge, MA.

Schwens C, Steinmetz H dan Kabst R. 2015. “Disentangling The Effect of Prior Entrepreneurial Exposure on Entrepreneurial Intention." Journal of Business Research. 68(3): 639-653.

Sénchez, V. B., dan Sahuquillo, C. A. 2012. "Entrepreneurial Behavior: Impact of Motivation Factors on Decision to Create a New Venture." Investigaciones Europeas a'e Direccio'n y Economia de la Empresa, 18: 132-138.

Serinkan, C., Kaymakçi, K., Arat, G., dan Avcik, C. 2013. "An Empirical Study on Intrapreneurship: In A Service Sector in Turkey." Procedia -Social and Behavioral Sciences 89: 715-719.

Shane, S., dan Venkataraman, S. 2000. "The Promise of Entrepreneurship as a Field of Research." Academy of Management Review 25(1): 217-226.

Shane, S., Locke, E. A., dan Collins, C. J. 2003. "Entrepreneurial Motivation." Human Resource Management Review 13(2): 257279.

Shapero, A., dan Sokol, L. 1982. Social dimensions of entrepreneurship. In C. A. Kent, D. L. Sexton, dan K. H. Vesper (Eds.), Encyclopedia of entrepreneurship (pp. 72-90). Prentice-Hall. Englewood Cliffs. 
Shaver, K.G., dan Scott, L.R. 1991. “Person, Process, Choice: The Psychology of New Venture Creation." Entrepreneurship Theory and Practice: 23-45.

Sheldon, M. 1971. "Investments and Involvement as Mechanisma Producing Commitment to the Organization." Administrative Science Quarterly, 16: 142-150.

Shinnar, R.S, Giacomin, O dan Janssen, F. 2012. "Entrepreneurial Perceptions and Intentions: The Role of Gender and Culture." Entrep Theory Pract. 36: 465-493

Souitaris, V., Zerbinati, S., dan Al-Laham, A. 2007. “Do Entrepreneurship Programmes Raise Entrepreneurial Intention of Science and Engineering Students? The effect of Learning, Inspiration and Resources." Journal of Business Venturing 22(4): 566-591.

Sparrow. 1998. Achievement and Motivation, University of Sheffield Management School, UK: 639-663.

Spence, J. T. and Heilmreich, R. L. 1983. Achievement related motives and behaviors. In J. T. Spence (Ed.), Achievement and Achievement Motives. San Francisco: Free Press: 167.

Swailes, S. 2003. "Professionalism: Evolution and Measurement." The Service Industries Journal 23(2): 130-159.

Teoh, H. Y., dan Foo, S. L. 1997. "Moderating effects of Tolerance for Ambiguity and Risk-Taking Propensity on the Role Conflict-Perceived Performance Relationship: evidence from Singaporean Entrepreneurs." Journal of Business Venturing. 12(1): 67-81.

Thompson, E. R. 2009. "Individual Entrepreneurial Intent: Construct Clarification and Development of an Internationally Reliable Metric." Entrepreneurship Theory and Practice 33(3): 669-694.
Venkataraman, S. 1997. "The distinctive domain of entrepreneurship research." In Advances in entrepreneurship, firm emergence and growth. JAI Press Inc. 3: 119-138.

Ventura, R, Quero, M. J. 2013. "Factores Explicativos de la Intención de Emprender en la Mujer." Aspectos diferenciales en la población universitaria según la variable género." Cuadernos de Gestión 13(1): 127-149.

Verheul, I., Thurik, R., Grilo, I., dan van der Zwan, P. 2012. “Explaining Preferences and Actual Involvement in Self-Employment: Gender and the Entrepreneurial Personality." Journal of Economic Psychology 33: 325-341.

Weseley, A. J., dan McEntarffer, R. 2010. Barron's AP psychology. 4th ed. Barron's Educational Series, Inc. New York.

Wright, P. M., dan Kehoe, R. R. 2007. "Human Resource Practices and Organizational commitment: A Deeper Examination." Asia Pacific Journal of Human Resources 46(1):6.

$\mathrm{Wu}, \mathrm{S}$., dan $\mathrm{Wu}, \mathrm{L}$. 2008. "The Impact of Higher Education on Entrepreneurial Intentions of University Students in China. Journal of Small Business and Enterprise Development 15(4): 752-774.

Yurtkoru, E. S., Acar, P., dan Teraman, B. S. 2014. "Willingness to Take Risk and Entrepreneurial Intention of Uni Students: An Empirical Study Comparing Private and State Universities." Social and Behavioral Sciences 150: 834840.

Zapkau, F.B., Schwens, C., Steinmetz, H., dan Kabst, R. 2015. “Disentangling the Effect of Prior Entrepreneurial Exposure on Entrepreneurial Intention." Journal of Business Research 68(3): 639-653. 